\title{
Gel combustion synthesis of fluorine-doped tin oxide and its characteristics: applying D-optimal factorial design of experiment
}

\author{
S MALEK $^{1}$, S BAGHSHAHI ${ }^{2, *}$, R SARRAF-MAMOORY $^{3}$ and ALI NEMATI ${ }^{4}$ \\ ${ }^{1}$ Department of Materials Engineering, Science and Research Branch, Islamic Azad University, Tehran 1477893855, Iran \\ ${ }^{2}$ Department of Materials Science and Engineering, Faculty of Engineering, Imam Khomeini International University, \\ Qazvin 3414896816, Iran \\ ${ }^{3}$ Department of Materials Engineering, Tarbiat Modares University, Tehran 1411713116, Iran \\ ${ }^{4}$ Department of Materials Science and Engineering, Sharif University of Technology, Tehran 11365-9466, Iran \\ *Author for correspondence (baghshahi@eng.ikiu.ac.ir)
}

MS received 6 June 2018; accepted 19 September 2018; published online 4 April 2019

\begin{abstract}
Fluorine-doped tin oxide (FTO) nano-powders were synthesized by a gel combustion method. To analyse the effect of processing factors and their interactions and to achieve an equation for nano-powder particle size in terms of code factors, D-optimal factorial design was used. Stannous chloride penta-hydride, ammonium fluoride and citric acid were used to synthesize the FTO nano-powders. The structure, morphology and composition of the synthesized powders were characterized by X-ray diffraction, field emission scanning electron microscopy and X-ray photoelectron spectroscopy, respectively. The results revealed the formation of homogenous FTO nano-powders with an average particle size of $20 \mathrm{~nm}$ and equiaxed morphology in the concentration of precursor 0.2 , citric acid to precursor molar ratio of 1 and $\mathrm{pH}$ of 0.5 . The average particle size increased as the concentration of the precursor, citric acid to precursor molar ratio and $\mathrm{pH}$ increased from 0.2 to 1,1 to 3 and 0.5 to 3 , respectively. Citric acid to precursor molar ratio, concentration of the precursor and the $\mathrm{pH}$ had the most significant effect on the synthesis of the FTO nano-powders, respectively.
\end{abstract}

Keywords. Gel combustion; FTO; D-optimal factorial design; solar cells.

\section{Introduction}

Transparent conductive oxides have recently been used as a substrate for titanium oxide photo electrodes in solar cells [1]. Thin, transparent conductive materials such as fluorinedoped tin oxide (FTO), indium tin-doped oxide (ITO) and antimony-doped tin oxide are widely used in various fields, such as solar cells for the suitable combination of electrical, optical and chemical properties [2]. ITO film has been widely used for many years. Compared to the high cost and toxicity of indium [3] on one hand, and an increase in its electrical resistance at the temperature of $300^{\circ} \mathrm{C}$ or higher [4] on the other hand, transparent conductive oxide films are inexpensive and more efficient. Hence, transparent conductive oxides, especially $\mathrm{SnO}_{2}: \mathrm{F}$ (FTO) is considered promising by researchers for solar cell applications.

FTO has high thermal stability and high chemical stability [3], hardness and can resist high temperatures [5]. Also, it has more transparency for lower resistant surface compared to antimony [6].

Both doped and undoped $\mathrm{SnO}_{2}$ have been synthesized by a variety of techniques, such as chemical precipitation [7], hydrothermal process [8], sol-gel [9-12] and sol-gel combustion [13].
Sol-gel combustion is a combination of the chemical solgel process and the combustion process [14]. This method is simpler and more efficient for producing nanoparticles with a narrow size distribution [9]. Inexpensive precursors, a simple preparation technique and the resulting nano-sized powder are the benefits of this process [13].

A widely used approach which researchers have employed is one factor at a time (OFAT), through which there is a change in one factor level with others being fixed during the experiment. This is followed by determining the level which brings up the results. Then, the factor level remains fixed while the others change [15]. However, the interactions between the factors cannot be predicted via this method. Also, achieving an optimal result is not guaranteed. Besides, changing OFAT is problematic due to the inability and insufficiency in the prediction of the effects caused by several factors [16]. In engineering experiments, statistical methods play a significant role in planning, conducting, analysing and interpreting data. When the properties of a product are influenced by several variables, designing a valid and reliable design seems necessary to obtain efficient and safe results [17].

In this study, the effective parameters in sol-gel combustion synthesis of FTO nano-powder are optimized by D-optimal, factorial design of experiment and the 
most important parameter and order of effect is distinguished.

\section{Experimental}

\subsection{Raw materials}

All the materials used in the experiment were of analytical grade. $\mathrm{SnCl}_{4} \cdot 5 \mathrm{H}_{2} \mathrm{O}$ and $\mathrm{NH}_{4} \mathrm{~F}$ were used as the precursors of tin and fluorine, respectively. Citric acid was used as the fuel, ammonium hydroxide was used for adjusting $\mathrm{pH}$ and deionized water as the solvent and the hydrolysis agent.

\subsection{Design of experiments}

Three factors with three levels were chosen as independent input factors: the concentration of the precursor (C), the fuel

Table 1. Selected factors and their levels.

\begin{tabular}{|c|c|c|c|c|}
\hline Selected factor & Units & $\begin{array}{l}\text { Level } 1 \\
(-1)^{\mathrm{a}}\end{array}$ & $\begin{array}{l}\text { Level } 2 \\
(0)^{\mathrm{a}}\end{array}$ & $\begin{array}{c}\text { Level } 3 \\
(1)^{\mathrm{a}}\end{array}$ \\
\hline Concentration & Molar & 0.2 & 0.6 & 1 \\
\hline $\begin{array}{l}\text { Fuel to precursor molar } \\
\text { ratio (portion) }\end{array}$ & - & 1 & 2 & 3 \\
\hline $\mathrm{pH}$ solution & - & 0.5 & 1.5 & 3 \\
\hline
\end{tabular}

${ }^{\mathrm{a}}$ The numbers in the parentheses show the coded form of the levels. to precursor molar ratio $(\mathrm{R})$ and the $\mathrm{pH}$ of the solution $(\mathrm{P})$. Factors and their levels are shown in table 1 and the experiments are shown in table 2. To avoid the influence of uncontrolled variables, the experiments were done randomly.

D-optimal designs were used rather than the standard classical designs for two main reasons: first, for the experiment, the fractional factorial design needs a lot of runs and secondly the design space is limited. In other words, the settings of the factors cannot be changed [18].

The particle size of the desired variable gained its minimum which was followed by the statistical analysis of experiments via Design-Expert 7 software.

To explain the relationship for each response and tested factors, a second order linear polynomial (regression) model was applied to the investigated factors as follows:

$$
Y=b_{0}+\sum b_{j} X_{j}+\sum b_{i j} X_{i} X_{j}+\varepsilon,
$$

in which $i$ and $j$ vary from 1 to the number of factors; $b_{0}$, a coefficient showing the mean of responses of all the experiments; $b_{i}$, a coefficient showing the effect of the factor $X_{i}$ and $b_{i j}$ the coefficient of regression showing the effects of interactions of factors $X_{i} X_{j}$ and $\varepsilon$ the experimental error [19].

\subsection{Sample preparation}

Considering the conditions discussed in table 2, the process of nano-powder FTO synthesis is as follows. Appropriate amount of $\mathrm{SnCl}_{4} \cdot 5 \mathrm{H}_{2} \mathrm{O}$ was dissolved in an appropriate

Table 2. D-optimal design of experiments, experimental sequences, response and predicted results.

Response (particle size)

Sample coded Standard order Run order Factor $A$ (molar) $\quad$ Factor $B$ Factor $C$ By experiment By using equation (3)

\begin{tabular}{|c|c|c|c|c|c|c|c|}
\hline $\mathrm{C}_{0.2} \mathrm{R}_{2} \mathrm{P}_{0.5}$ & 1 & 13 & 0.2 & 2 & 0.5 & $1 \pm 80$ & 79.11 \\
\hline $\mathrm{C}_{1} \mathrm{R}_{3} \mathrm{P}_{3}$ & 2 & 1 & 1 & 3 & 3 & $1 \pm 310$ & 310.96 \\
\hline $\mathrm{C}_{0.2} \mathrm{R}_{1} \mathrm{P}_{1.5}$ & 3 & 19 & 0.2 & 1 & 1.5 & $1 \pm 40$ & 39.98 \\
\hline $\mathrm{C}_{1} \mathrm{R}_{2} \mathrm{P}_{0.5}$ & 4 & 8 & 1 & 2 & 0.5 & $1 \pm 180$ & 182.92 \\
\hline $\mathrm{C}_{0.6} \mathrm{R}_{2} \mathrm{P}_{1.5}$ & 5 & 10 & 0.6 & 2 & 1.5 & $1 \pm 170$ & 172.42 \\
\hline $\mathrm{C}_{0.2} \mathrm{R}_{3} \mathrm{P}_{0.5}$ & 6 & 3 & 0.2 & 3 & 0.5 & $1 \pm 105$ & 111.19 \\
\hline $\mathrm{C}_{0.6} \mathrm{R}_{1} \mathrm{P}_{3}$ & 7 & 9 & 0.6 & 1 & 3 & $1 \pm 132$ & 131.12 \\
\hline $\mathrm{C}_{1} \mathrm{R}_{3} \mathrm{P}_{1.5}$ & 8 & 5 & 1 & 3 & 1.5 & $1 \pm 270$ & 269.48 \\
\hline $\mathrm{C}_{0.2} \mathrm{R}_{3} \mathrm{P}_{1.5}$ & 9 & 14 & 0.2 & 3 & 1.5 & $1 \pm 125$ & 122.14 \\
\hline $\mathrm{C}_{1} \mathrm{R}_{2} \mathrm{P}_{1.5}$ & 10 & 12 & 1 & 2 & 1.5 & $1 \pm 208$ & 204.20 \\
\hline $\mathrm{C}_{0.2} \mathrm{R}_{2} \mathrm{P}_{1.5}$ & 11 & 17 & 0.2 & 2 & 1.5 & $1 \pm 100$ & 99.96 \\
\hline $\mathrm{C}_{1} \mathrm{R}_{1} \mathrm{P}_{0.5}$ & 12 & 16 & 1 & 1 & 0.5 & $1 \pm 55$ & 55.01 \\
\hline $\mathrm{C}_{0.2} \mathrm{R}_{1} \mathrm{P}_{0.5}$ & 13 & 15 & 0.2 & 1 & 0.5 & $1 \pm 20$ & 19.99 \\
\hline $\mathrm{C}_{1} \mathrm{R}_{1} \mathrm{P}_{3}$ & 14 & 11 & 1 & 1 & 3 & $1 \pm 175$ & 175.22 \\
\hline $\mathrm{C}_{0.2} \mathrm{R}_{1} \mathrm{P}_{3}$ & 15 & 2 & 0.2 & 1 & 3 & $1 \pm 75$ & 75.47 \\
\hline $\mathrm{C}_{0.6} \mathrm{R}_{3} \mathrm{P}_{0.5}$ & 16 & 6 & 0.6 & 3 & 0.5 & $1 \pm 225$ & 222.57 \\
\hline $\mathrm{C}_{0.6} \mathrm{R}_{2} \mathrm{P}_{0.5}$ & 17 & 18 & 0.6 & 2 & 0.5 & $1 \pm 148$ & 147.37 \\
\hline $\mathrm{C}_{0.6} \mathrm{R}_{3} \mathrm{P}_{3}$ & 18 & 4 & 0.6 & 3 & 3 & $1 \pm 245$ & 246.23 \\
\hline $\mathrm{C}_{0.6} \mathrm{R}_{2} \mathrm{P}_{3}$ & 19 & 7 & 0.6 & 2 & 3 & $1 \pm 215$ & 215.45 \\
\hline
\end{tabular}

${ }^{a}$ This column is calculated using equation (3) after doing analysis of variance and is shown here to compare the predicted and experimental results. 
volume of deionized water under continuous stirring condition and heated to prepare a clear solution, a certain amount of $\mathrm{NH}_{4} \mathrm{~F}$ was added so that the concentration of fluorine is set based on the mole ratio of $[\mathrm{F}] /[\mathrm{Sn}]=0.1$. Then, citric acid with an appropriate molar ratio was added to this solution as a fuel. This was followed by the addition of $\mathrm{NH}_{4} \mathrm{OH}$ aqueous solution drop by drop under constant stirring condition until the desired $\mathrm{pH}$ was achieved and it turned to a sol. While the solution was heated, the sol changed to gel. Then, the gel was heated until it was dry. The dried gels were heated in a furnace at $350^{\circ} \mathrm{C}$ for $1 \mathrm{~h}$, resulting in their auto-combustion. Finally, the powders were calcined at $600^{\circ} \mathrm{C}$ for $1 \mathrm{~h}$.

\subsection{Characterization}

Powder X-ray diffraction (XRD; Scifert, 3003 PTS model) was employed to determine the characteristics of synthesized powder such as crystal structure and phase type.

By using Scherrer equation (2) and software X'pert highscore plus analytical, crystallite size was calculated:

$$
D_{h k l}=\frac{0.9 \lambda}{\cos \theta \sqrt{\left(\beta_{\mathrm{m}}^{2}-\beta_{\mathrm{S}}^{2}\right)}},
$$

where $D_{h k l}$ is the average crystallite size, $\lambda$ the X-ray wavelength, $\beta_{\mathrm{m}}$ the full width at half maximum of the diffraction peak that was calculated by $X$ 'pert high score software, $\beta_{\mathrm{s}}$ the full width at half maximum of the diffraction peak for the standard sample which is 0.15868 and $\theta$ the Braggs diffraction angle. Particle morphology and size were observed by using a field emission scanning electron microscope (FESEM; TESCAN, MIRA3 LMU) and the grain size was reckoned by Image-J software which was considered as a response in experimental designs. The surface composition was examined by X-ray photoelectron spectroscopy (XPS, Bestec, ESCA system) with AlK $\alpha$ radiation. Fluorine content in tin dioxide was studied by electrochemical measurement technologies by a PF-4C (204) fluoride ion electrode instrument.

\section{Results and discussion}

\subsection{Metallurgical characterization}

Figure 1 shows the XRD patterns of 19 samples calcined at $600^{\circ} \mathrm{C}$. The XRD results showed the characteristic peaks of cassiterite structure of $\mathrm{SnO}_{2}$ crystals, and all the peaks
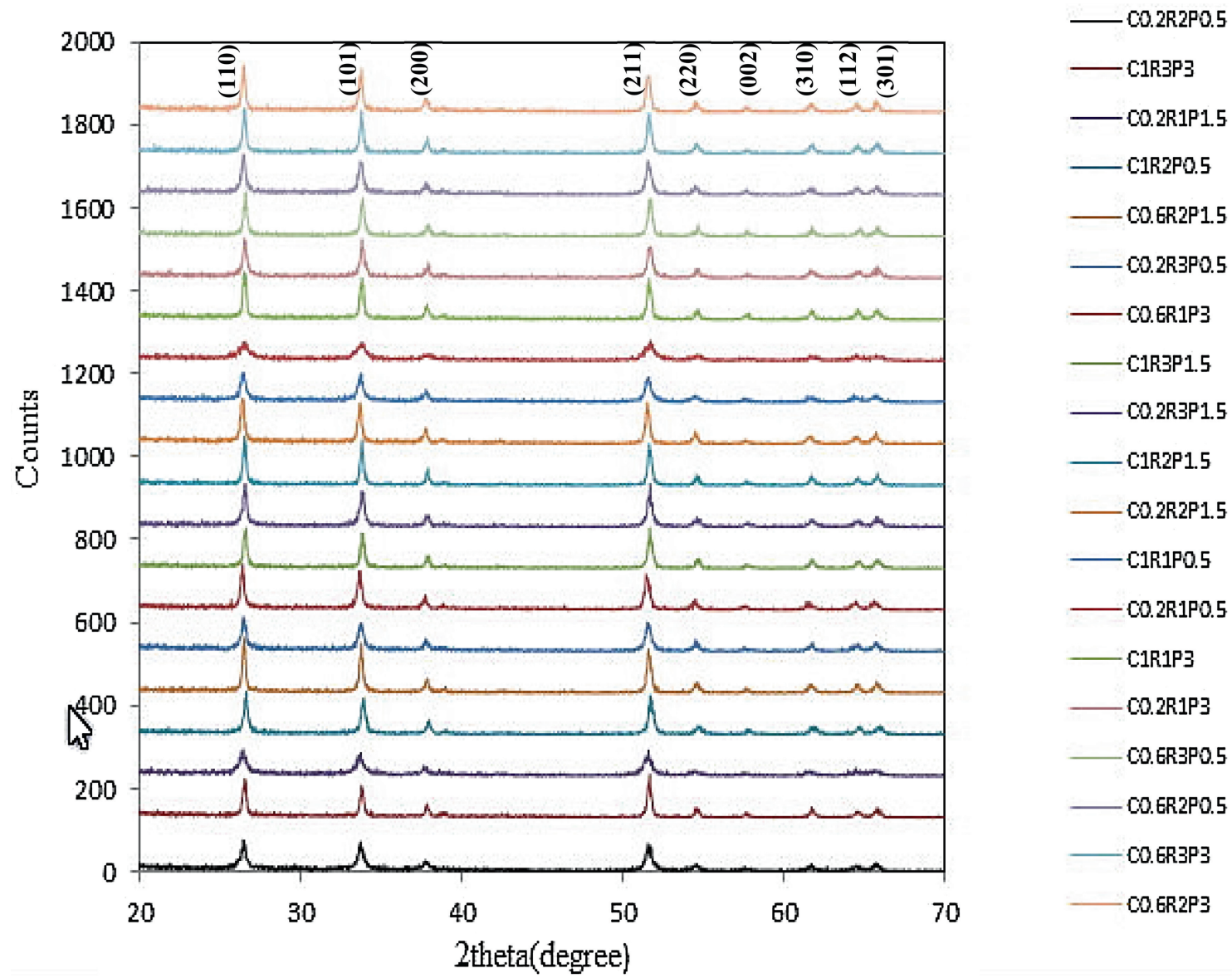

Figure 1. XRD patterns of FTO sample. 
Table 3. Crystallite size of the samples

\begin{tabular}{lr}
\hline Sample code & Crystallite size (nm) \\
\hline $\mathrm{C}_{0.2} \mathrm{R}_{2} \mathrm{P}_{0.5}$ & $8.5 \pm 0.5$ \\
$\mathrm{C}_{1} \mathrm{R}_{3} \mathrm{P}_{3}$ & $18 \pm 0.5$ \\
$\mathrm{C}_{0.2} \mathrm{R}_{1} \mathrm{P}_{1.5}$ & $7 \pm 0.5$ \\
$\mathrm{C}_{1} \mathrm{R}_{2} \mathrm{P}_{0.5}$ & $13.5 \pm 0.5$ \\
$\mathrm{C}_{0.6} \mathrm{R}_{2} \mathrm{P}_{1.5}$ & $15 \pm 0.5$ \\
$\mathrm{C}_{0.2} \mathrm{R}_{3} \mathrm{P}_{0.5}$ & $11.5 \pm 0.5$ \\
$\mathrm{C}_{0.6} \mathrm{R}_{1} \mathrm{P}_{3}$ & $15 \pm 0.5$ \\
$\mathrm{C}_{1} \mathrm{R}_{3} \mathrm{P}_{1.5}$ & $18 \pm 0.5$ \\
$\mathrm{C}_{0.2} \mathrm{R}_{3} \mathrm{P}_{1.5}$ & $14.5 \pm 0.5$ \\
$\mathrm{C}_{1} \mathrm{R}_{2} \mathrm{P}_{1.5}$ & $17 \pm 0.5$ \\
$\mathrm{C}_{0.2} \mathrm{R}_{2} \mathrm{P}_{1.5}$ & $15.5 \pm 0.5$ \\
$\mathrm{C}_{1} \mathrm{R}_{1} \mathrm{P}_{0.5}$ & $9.8 \pm 0.5$ \\
$\mathrm{C}_{0.2} \mathrm{R}_{1} \mathrm{P}_{0.5}$ & $5 \pm 0.5$ \\
$\mathrm{C}_{1} \mathrm{R}_{1} \mathrm{P}_{3}$ & $16 \pm 0.5$ \\
$\mathrm{C}_{0.2} \mathrm{R}_{1} \mathrm{P}_{3}$ & $14 \pm 0.5$ \\
$\mathrm{C}_{0.6} \mathrm{R}_{3} \mathrm{P}_{0.5}$ & $18.5 \pm 0.5$ \\
$\mathrm{C}_{0.6} \mathrm{R}_{2} \mathrm{P}_{0.5}$ & $12 \pm 0.5$ \\
$\mathrm{C}_{0.6} \mathrm{R}_{3} \mathrm{P}_{3}$ & $17.7 \pm 0.5$ \\
$\mathrm{C}_{0.6} \mathrm{R}_{2} \mathrm{P}_{3}$ & $17.0 \pm 5$ \\
\hline
\end{tabular}

were well indexed to the pure phase patterns (JCPDS card no. 04-077-045). No obvious reflection peaks of impurities, such as unreacted $\mathrm{Sn}$ or $\mathrm{SnO}$ were observed indicating the suitable design condition of the experiment. Using Scherrer formula to broaden the diffraction peaks, the mean crystallite size of the tin oxide crystals is shown in table 3.

Figures 2 and 3 show the FESEM photographs of 19 samples calcined at $600^{\circ} \mathrm{C}$. The particle size and morphology of the synthesized FTO powders rely on the condition of the experimental design. The mean particle size of the powders obtained using Image-J software is given in table 2.

\subsection{Analysis of design of experiment}

In analysis of variance (table 4), the results of the D-optimal factorial design of experiment are presented with a confidence interval (CI) of $95 \%$ for the model. Based on the results of table 4 and by considering the contribution of each main effect and interactions, three main effects, five two-factor interactions and three three-factor interactions were chosen as significant factors for modelling.

Analysis of variance results for particle size show a significant model with adequate precision of 156.262. 'Adequate precision' measures the signal to noise ratio and a ratio $>4$ is needed [20]. The ratio of the present model is 156.262 which indicates an adequate signal. This model can be used to navigate the design space without doing any further experiments. The quality of the fittings of the equations was expressed by the coefficient of regression 'adjusted $R^{2}$, or in a better way by 'predicted $R^{2}$. The 'adjusted $R^{2}$, values indicate variability in the observed response values which can be explained by the experimental factors and their interactions. For a good model and for the better fitting, the differences between adjusted $R^{2}$ and predicted $R^{2}$ should be $<0.2$ and closer to 1 [21,22]. The 'predicted $R^{2}$, of 0.9974 is in reasonable agreement with the 'adjusted $R^{2}$, of 0.994. According to the $F$-test in the proposed model $\left(F_{\text {model }}=1779.20 \gg F_{\text {table }}(11,7)=3.6365\right)$, the model $F$-value of 177.90 implies that the model is significant and there is only a $0.01 \%$ chance that a 'model $F$-value' could occur due to noise [21]. Using this model (equation (2)), we can navigate the design space. The relationship between the actual and predicted values shown in figure 4 and table 2 is a confirmation of the navigation power of the model.

To check the data normality, the normal probability plot of the residuals are plotted. The closer the data points on the plot to the straight line, the more normally the data is distributed [20].The plot of residuals for particle size showed that the data had a normal distribution as shown in figure 5 .

Analysis of the regression coefficients of the linear polynomial model describes the relationship between the response and factors which is shown in equation (3). The coded values (table 1) of factors must be inserted.

$$
\begin{aligned}
\left(R_{1}\right)^{0.29}= & +4.50+0.44 A+0.68 B+0.25 C+0.082 A B \\
& +0.03 A C-0.26 B C-0.21 A^{2}-0.31 B^{2} \\
& -0.090 A^{2} B+0.086 A C^{2}+0.088 B^{2} C
\end{aligned}
$$

Each factor's importance in the process is determined by the sum of squares and as the value of it increases, the significance of the corresponding factor in the undergoing process also increases. As shown in table 4 , the effect of $B$ is the highest which is followed by the effect of $A$, the interaction of $B$ and $C$, the interaction of $B$ and $B, C$, the interaction of $A$ and $A$, interaction of $A$ and $B$, the interaction of $B^{2}$ and $C$, the interaction of $A$ and $C^{2}$, the interaction of $A^{2}$ and $B$ and the interaction of $A$ and $C$, respectively.

If the model equation is determined in actual terms, it can be found that the effects of $A, B, C, A B, A C, A C^{2}$ and $B^{2} C$ have positive (synergistic effect) and $B C, A^{2}, B^{2}, A^{2} B$ have negative (antagonism) influence on particle size. To decrease the size of the particles, the negative factors should be increased, whereas the positive factor should be reduced.

Figure $6 \mathrm{a}$ and $\mathrm{b}$ shows the effect of the main factors (concentration, portions) and figure $7 \mathrm{a}$ and $\mathrm{b}$ shows the effect of main factor $\mathrm{pH}$ and interactions $B C$, which implies that there was a rather important two-way interaction. From these figures, an optimum condition could be extracted which is $A-B-C$. By analysis of the interactions, the following results were achieved: figure $7 \mathrm{~b}$ shows $B-C$-resulted in a minimum particle size according to the main variables.

Three confirmation experiments were conducted under the condition of the concentration, fuel to precursor molar ratio (portion) and $\mathrm{pH}$ solution according to table 5. If the average of the results of the confirmation is within the limits of the CI, 

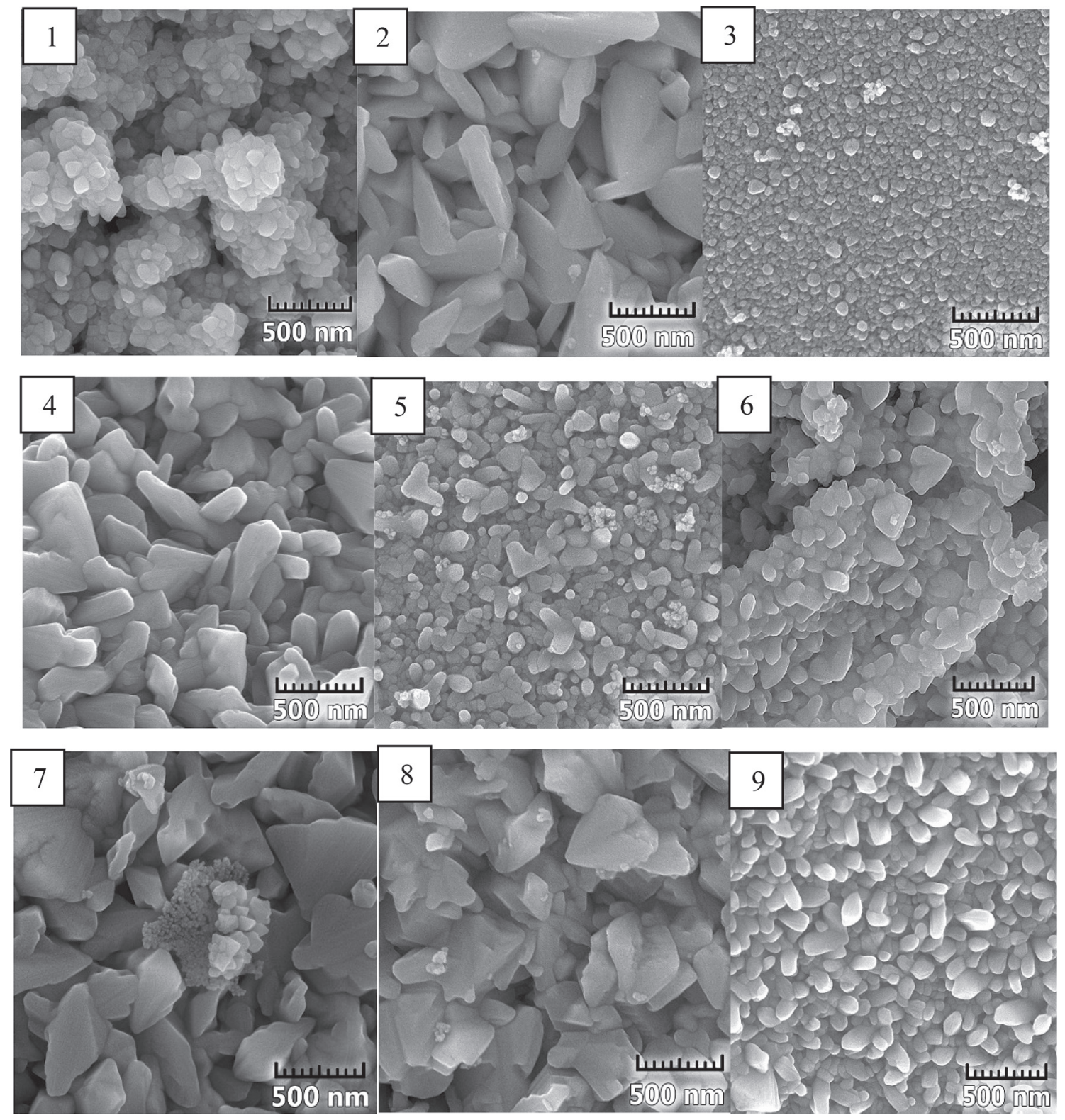

Figure 2. FESEM image of samples: (1) $\mathrm{C}_{0.2} \mathrm{R}_{2} \mathrm{P}_{0.5}$, (2) $\mathrm{C}_{1} \mathrm{R}_{3} \mathrm{P}_{3}$, (3) $\mathrm{C}_{0.2} \mathrm{R}_{1} \mathrm{P}_{1.5}$, (4) $\mathrm{C}_{0.6} \mathrm{R}_{2} \mathrm{P}_{1.5}$, (5) $\mathrm{C}_{0.2} \mathrm{R}_{3} \mathrm{P}_{0.5}$, (6) $\mathrm{C}_{0.6} \mathrm{R}_{1} \mathrm{P}_{3}$, (7) $\mathrm{C}_{1} \mathrm{R}_{3} \mathrm{P}_{1.5}$, (8) $\mathrm{C}_{1} \mathrm{R}_{2} \mathrm{P}_{1.5}$ and (9) $\mathrm{C}_{0.2} \mathrm{R}_{2} \mathrm{P}_{1.5}$.

then, the significant factors as well as the appropriate levels to obtain the desired results are properly chosen.

According to table 6, the results of particle size are within the limits of the CI range and this model can be used to navigate within the design space.

\subsection{Determination of the optimum conditions using D-optimal design of experiments}

The purpose of the test samples prepared in the synthesis of nano-powders is to obtain the minimum particle size and the contributing conditions which lead to it. The trial synthesized powder is sample $\mathrm{C}_{0.2} \mathrm{R}_{1} \mathrm{P}_{0.5}$ code with the lowest particle size, which has a particle size of $20 \mathrm{~nm}$. In this case, the concentration of precursor 0.2 , citric acid to precursor molar ratio of 1 and $\mathrm{pH}$ value of 0.5 were obtained. Figure $8 \mathrm{a}-\mathrm{c}$ shows XRD pattern, FESEM microstructure and XPS of $\mathrm{C}_{0.2} \mathrm{R}_{1} \mathrm{P}_{0.5}$ code, respectively. Photoelectron peaks for $\mathrm{F} 1 \mathrm{~s}$, Sn 3d, O 1s and C 1s were detected for the sample in the binding energy range of $0-1200 \mathrm{eV}$ as shown in figure 8c. The binding energies of the F 1s, Sn $3 \mathrm{~d}$ and $\mathrm{O} 1 \mathrm{~s}$ photoelectron peak are at 690, 492 and $536 \mathrm{eV}$, respectively. A C 1s peak at a binding energy of $290 \mathrm{eV}$ is also observed in the sample.

By using $\mathrm{SnCl}_{4} \cdot 5 \mathrm{H}_{2} \mathrm{O}$ as a precursor and citric acid as fuel, at temperatures below $300^{\circ} \mathrm{C}$, the precursor mixture did 

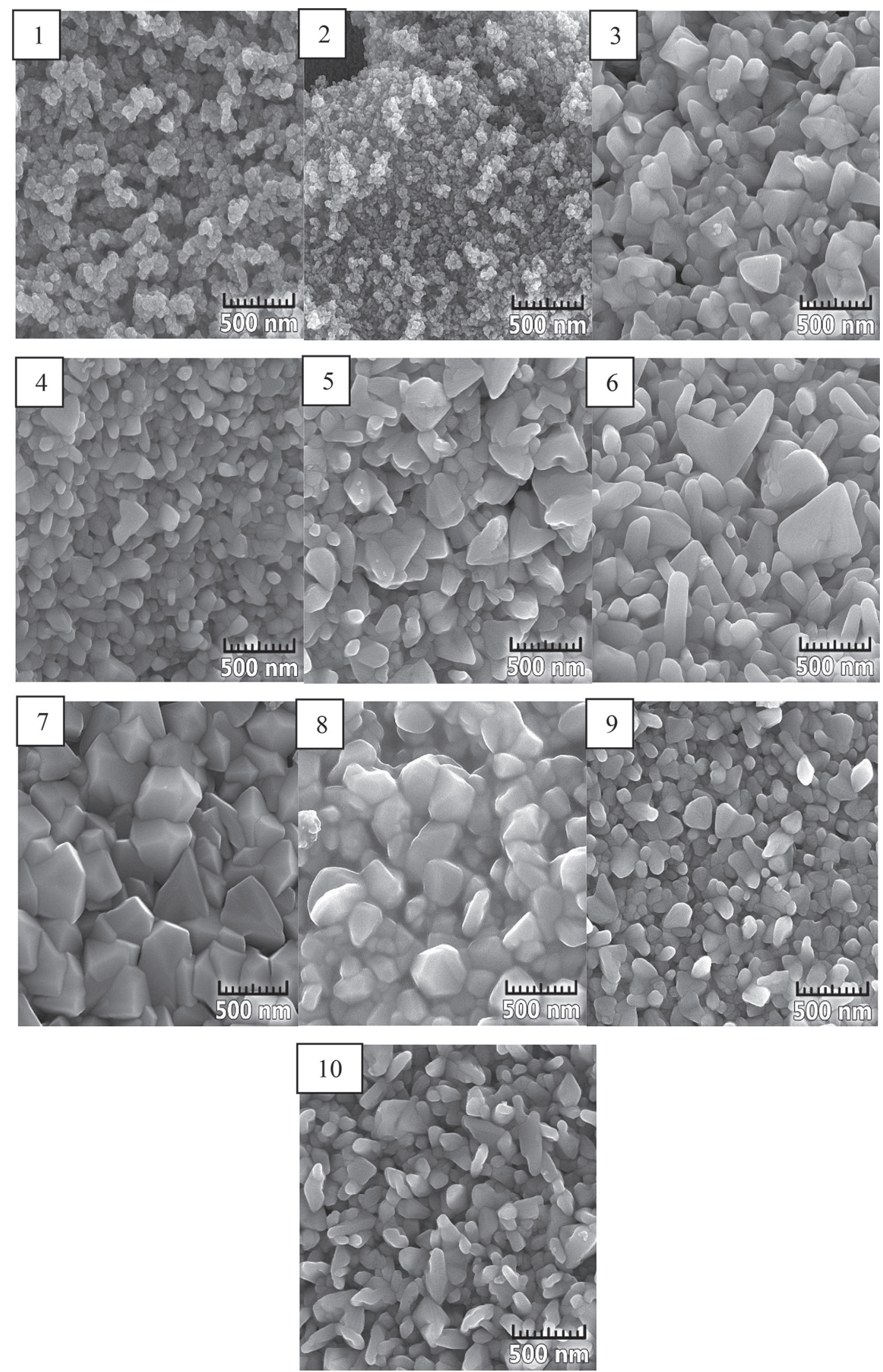

Figure 3. FESEM image of samples: (1) $\mathrm{C}_{1} \mathrm{R}_{1} \mathrm{P}_{0.5}$, (2) $\mathrm{C}_{0.2} \mathrm{R}_{1} \mathrm{P}_{0.5}$, (3) $\mathrm{C}_{1} \mathrm{R}_{1} \mathrm{P}_{3}$, , (4) $\mathrm{C}_{0.2} \mathrm{R}_{1} \mathrm{P}_{3}$, (5) $\mathrm{C}_{0.6} \mathrm{R}_{3} \mathrm{P}_{0.5}$, (6) $\mathrm{C}_{0.6} \mathrm{R}_{2} \mathrm{P}_{0.5}$, (7) $\mathrm{C}_{0.6} \mathrm{R}_{3} \mathrm{P}_{3}$, (8) $\mathrm{C}_{0.6} \mathrm{R}_{2} \mathrm{P}_{3}$, (9) $\mathrm{C}_{0.2} \mathrm{R}_{3} \mathrm{P}_{1.5}$ and (10) $\mathrm{C}_{1} \mathrm{R}_{2} \mathrm{P}_{0.5}$. 
Table 4. Analysis of variance with CI equal to $95 \%$ and $95 \%$ for models and factors, respectively.

\begin{tabular}{lcrcrrr}
\hline Source & Sum of squares & df & Mean square & $F$ value & $P$ value prob. $>F$ & \\
\hline Model & 10.67 & 11 & 0.97 & 1779.20 & $<0.0001$ & Significant $^{\mathrm{a}}$ \\
$A$, concentration & 0.80 & 1 & 0.80 & 1476.33 & $<0.0001$ & \\
$B$, portions & 1.12 & 1 & 1.12 & 2051.00 & $<0.0001$ \\
$C, \mathrm{pH}$ & 0.18 & 1 & 0.18 & 327.80 & $<0.0001$ \\
$A B$ & 0.041 & 1 & 0.041 & 75.39 & $<0.0001$ \\
$A C$ & $9.560 \times 10^{-003}$ & 1 & $9.560 \times 10^{-003}$ & 17.54 & $<0.0001$ \\
$B C$ & 0.44 & 1 & 0.44 & 807.02 & $<0.0001$ \\
$A^{2}$ & 0.15 & 1 & 0.15 & 267.56 & $<0.0001$ \\
$B^{2}$ & 0.31 & 1 & 0.31 & 565.40 & $<0.0001$ \\
$A^{2} B$ & 0.015 & 1 & 0.015 & 27.05 & 0.0013 \\
$A C^{2}$ & 0.016 & 1 & 0.016 & 28.97 & 0.0010 \\
$B^{2} C$ & 0.017 & 1 & 0.017 & 30.29 & 0.0009 \\
Residual $_{\text {Corr. total }}^{\mathrm{b}}$ & $3.815 \times 10^{-003}$ & 7 & $5.450 \times 10^{-004}$ & & \\
\hline
\end{tabular}

a The term 'significant' indicates that there is no chance that this model could occur due to noise.

${ }^{b}$ It is the total of all information corrected for the mean.

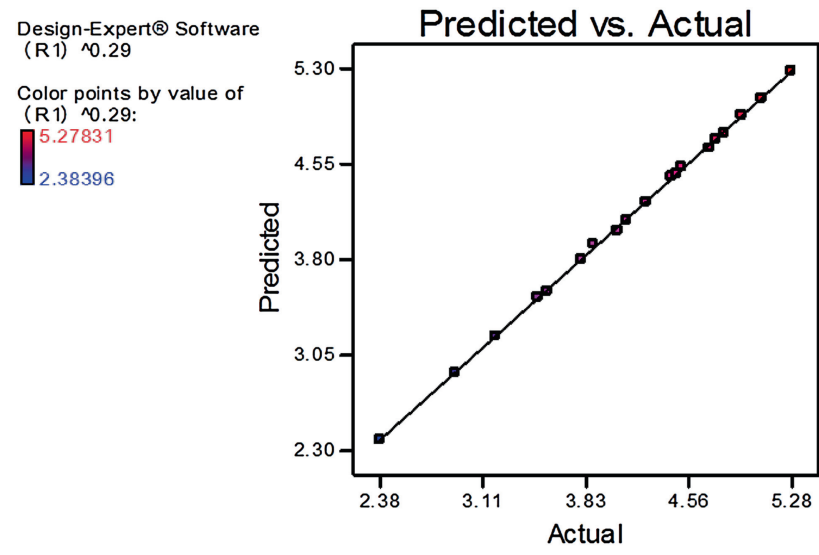

Figure 4. Comparison between predicted and actual particle size values.

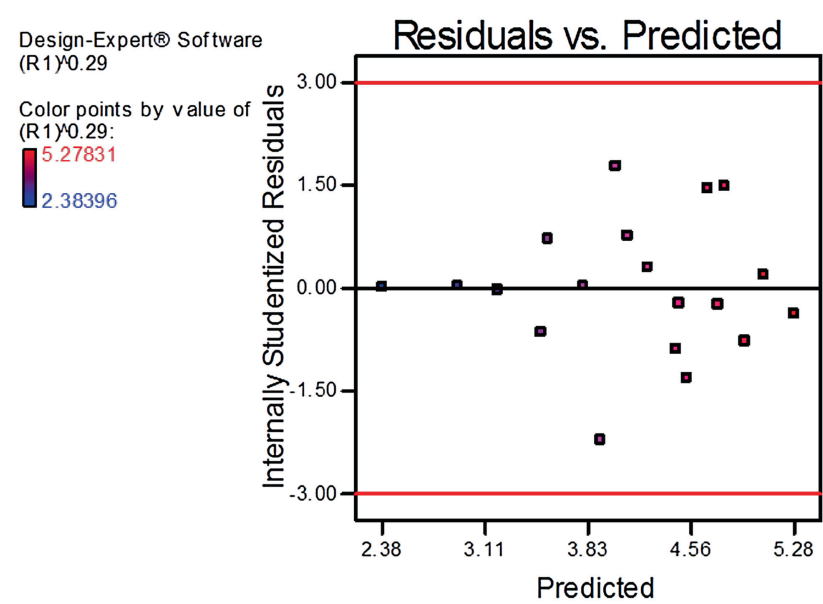

Design-Expert $\circledast$ Software Original Scale

$(\mathrm{R} 1)^{\wedge} 0.29$

$\mathrm{X} 1=\mathrm{A}:$ Concentration

Actual Factors B: Portions $=2.00$ B: Portions $=2.00$
$\mathrm{pH}=1.75$

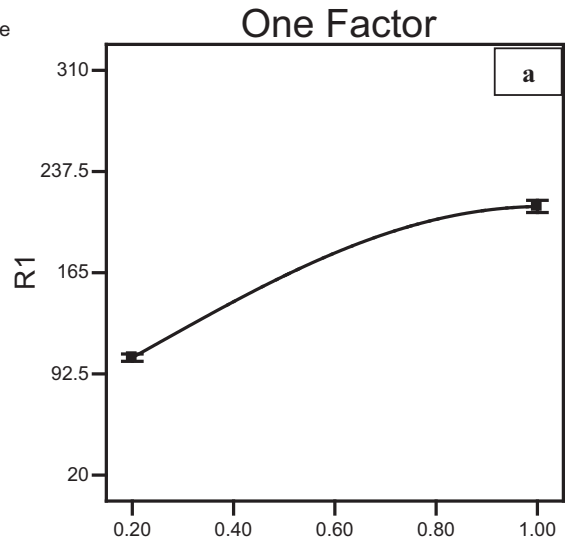

A: Concentration

Design-Expert $®$ Software Original Scale (R1)^ 0.29

$\mathrm{X} 1$ = B: Portions Actual Factors A: Concentration $=0.60$ $\mathrm{C}: \mathrm{pH}=1.75$

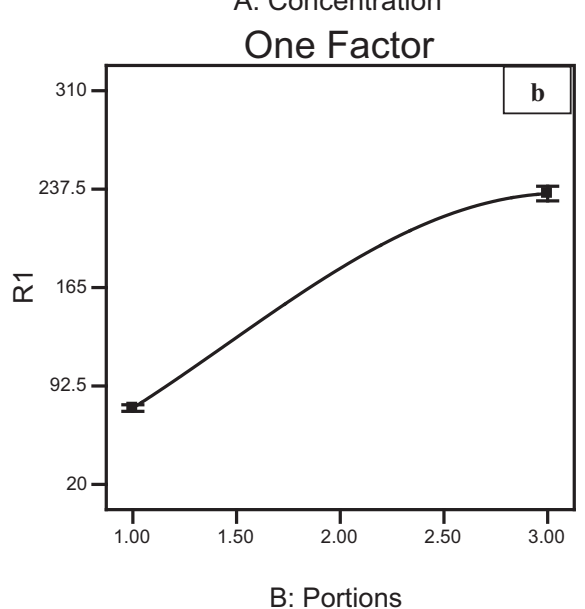

Figure 5. Internally studentized residuals $v s$. predicted.

Figure 6. (a, b) Effects of main parameters. 

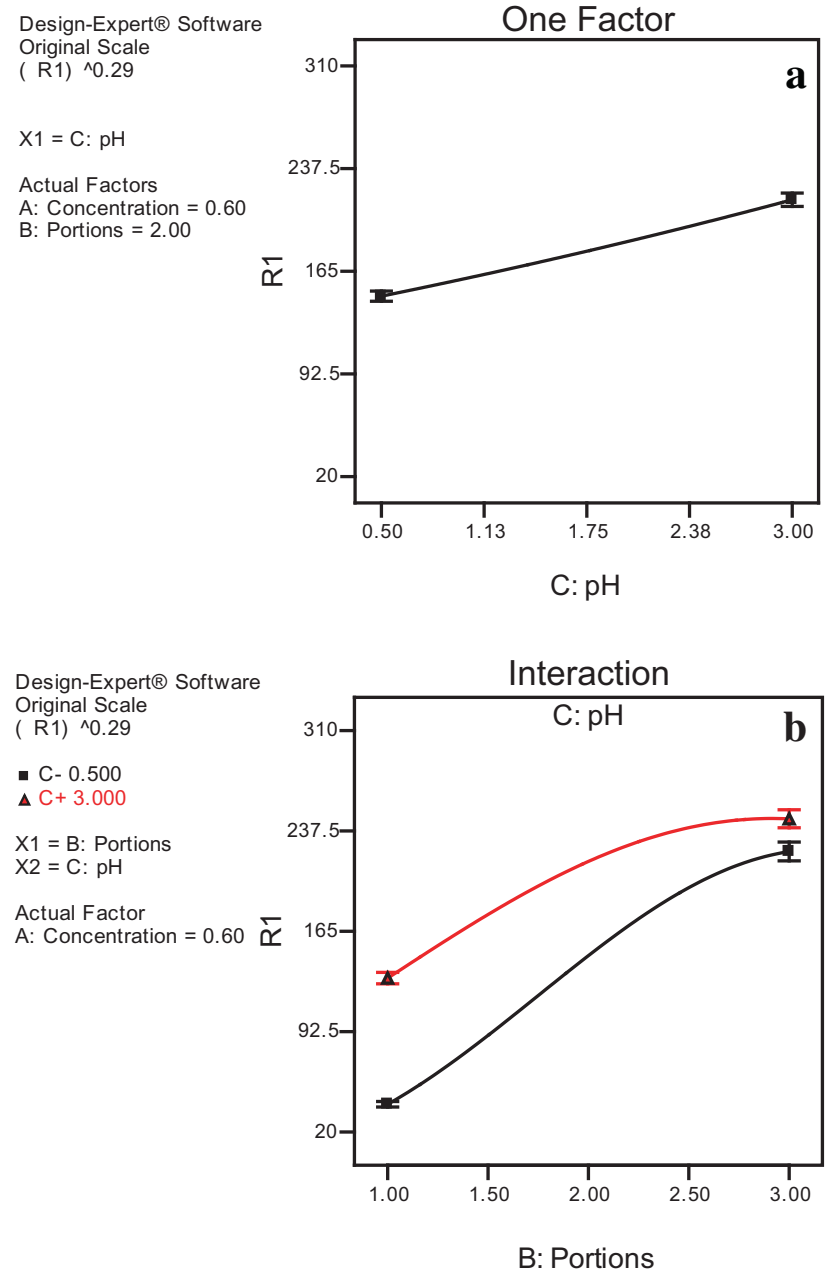

Figure 7. Effects of (a) main parameters and (b) important interactions.

Table 5. Parameters of tests for validation of model.

\begin{tabular}{lccc}
\hline Test & Concentration & Portions & $\mathrm{pH}$ \\
\hline 1 & 0.3 & 1.5 & 2.5 \\
2 & 0.7 & 2.5 & 1.5 \\
3 & 0.9 & 1.0 & 0.6 \\
\hline
\end{tabular}

Table 6. Results of particle size by experiment and using equation by model.

\begin{tabular}{lccrr}
\hline Test & $\begin{array}{c}\text { Particle size } \\
\text { (by experiment) }\end{array}$ & $\begin{array}{c}\text { Particle size } \\
\text { (by using equation (2) })\end{array}$ & $\begin{array}{c}\text { 95\% PI } \\
\text { low }\end{array}$ & $\begin{array}{c}\text { 95\% PI } \\
\text { high }\end{array}$ \\
\hline 1 & 110 & 108.268 & 102.10 & 114.69 \\
2 & 233 & 229.589 & 219.75 & 239.70 \\
3 & 55 & 54.60 & 50.31 & 59.16 \\
\hline
\end{tabular}

not react. At $350^{\circ} \mathrm{C}$, the precursor mixture reacted. From the XRD patterns of figure $9 \mathrm{a}$ and $\mathrm{b}$ before calcination at $600^{\circ} \mathrm{C}$, the crystalline phase was dominant and according to the width of the diffraction peak is composed of nano-size crystallite.
From the FESEM microstructures and XRD patterns in figures $1-3$, it can be concluded that when citric acid to raw material ratio, the concentration and the $\mathrm{pH}$ value are minimized, it resulted in a microstructure with finer and more homogeneous round structure in $\mathrm{C}_{0.2} \mathrm{R}_{1} \mathrm{P}_{0.5}$ sample code. Then, it can be concluded that an increase in citric acid to raw material ratio from 1 to 2 and 3 might lead to more heat release during combustion which results in combustion reaction enthalpy which itself causes complete combustion reaction and growth in the particle size. On the other hand, this is attributed to particle aggregation induced by the citrate. This suggests that the presence of citrate moiety promotes aggregation possibly by inducing charge accumulation on the surface leading to particles sticking together to form bigger particles. $\mathrm{SnO}_{2}$ particles changed from regular spheres to irregular ones and finally to polyhedron shape with an increase in citric acid concentration. The formation of polyhedron shape is thought to be due to self-assembly of smaller particles. Self-assembly growth is mediated by the thermodynamics of the system and it is also time-dependent [23].

Li et al [24] reported the effects of citric acid on hydrothermally-prepared $\mathrm{SnO}_{2}$. In their study, the presence of citric acid led to the formation of materials with a larger surface area. However, Sikhwivhilu et al [23] found out that the presence of citric acid in different concentrations led to grain growth and morphological transformation too. These results in this study are in agreement with Sikhwivhilu et al [23] and shows that the effects of citric acid are dependent on the method of preparation [23].

By considering the FESEM microstructures and XRD patterns in figures $1-3$, in $C_{0.2} R_{1} P_{0.5}$ sample code with 0.2 concentration, minimum particle size and a finer microstructure were obtained. It can be concluded that increasing the concentration from 0.2 to 1 results in the growth of the particle size of powder.

Bruneaux et al [25] investigated the effect of increased concentration in the preparation of a spray solution on the FTO layer deposition method in spray pyrolysis and showed that by increasing the concentration, particle size increases. This result is also in agreement with the results of this study.

According to FESEM microstructures and XRD patterns in figures $1-3$, when the $\mathrm{pH}$ is increased from 0.5 to 3 , there is a significant increase in both combustion reaction and volume of external gases because of the formation of oxidizing medium around metallic ions due to the nitrate ions which can be used in the burning of the organic part of the gel leading to increasing $\mathrm{pH}$ value and $\mathrm{NO}^{3-}$ ions. All these can increase the combustion reaction rate and growth of the grains of powder [26].

Adnan et al [12] synthesized tin oxide nanoparticles using a simple sol-gel method. They investigated that the surface area decreases with increasing ammonia concentration (increasing $\mathrm{pH})$ due to particle agglomeration. This result is also in agreement with the results of this study. 

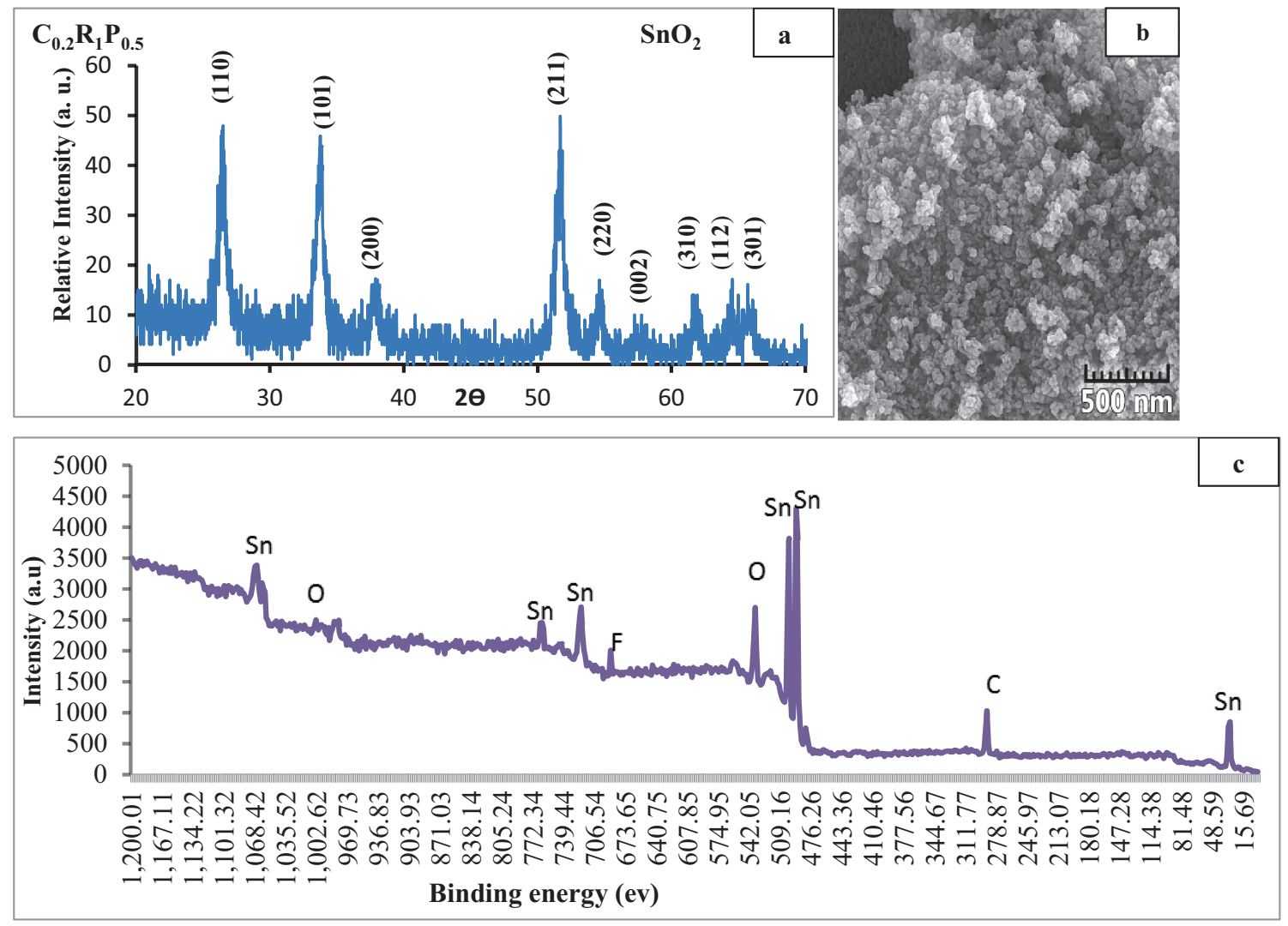

Figure 8. (a) XRD pattern, (b) FESEM micrograph and (c) XPS of $\mathrm{C}_{0.2} \mathrm{R}_{1} \mathrm{P}_{0.5}$ code.

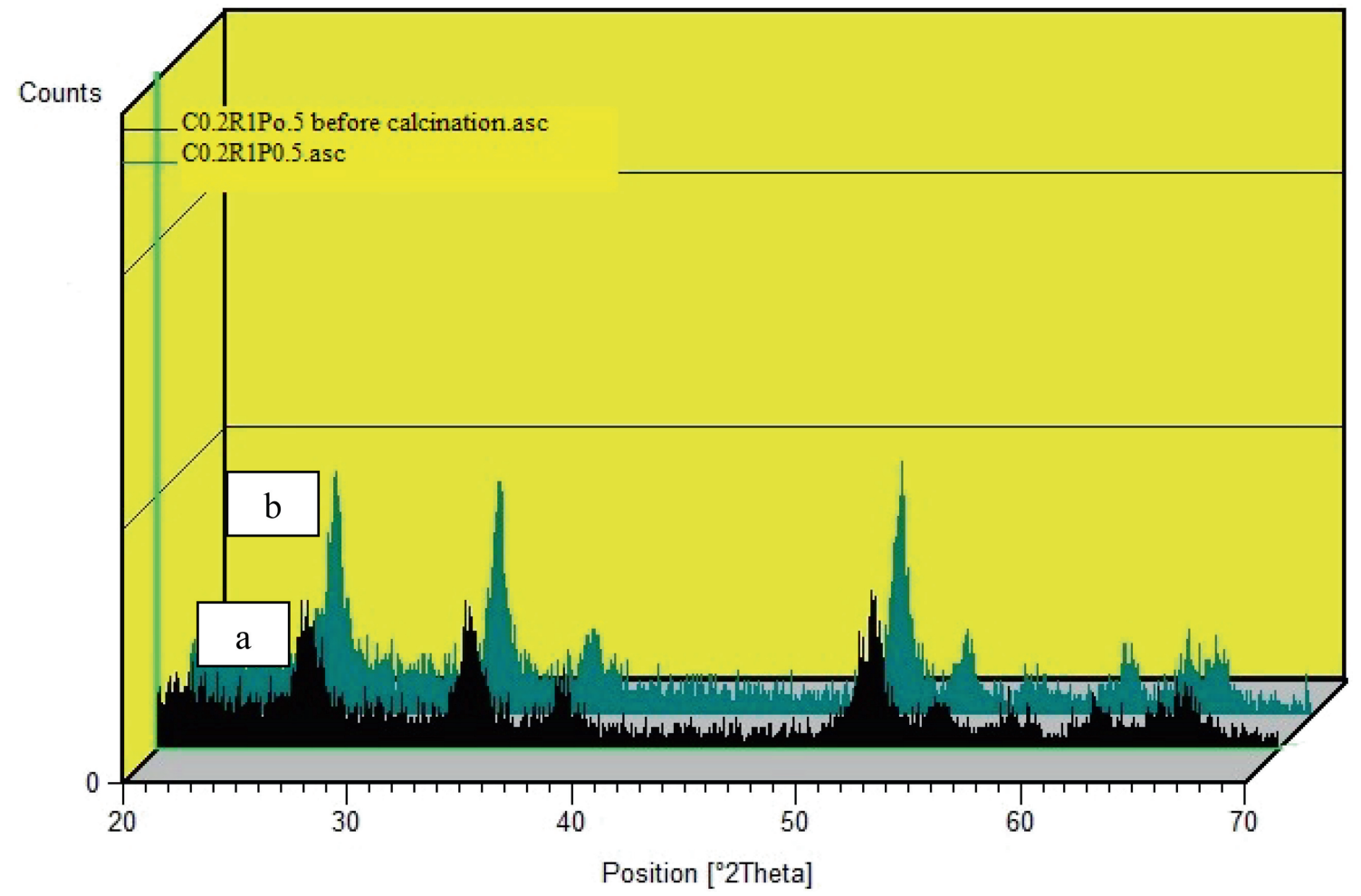

Figure 9. XRD pattern of $\mathrm{C}_{0.2} \mathrm{R}_{1} \mathrm{P}_{0.5}$ code: (a) after sol-gel combustion and (b) after calcination at $600^{\circ} \mathrm{C}$. 


\section{Conclusion}

FTO was successfully synthesized using a gel combustion method with citric acid as a fuel and D-optimal factorial design. The fuel to raw material ratio, the concentration and $\mathrm{pH}$ value had the most significant effect on the size of FTO nano-powder, respectively. The optimum synthesized powder had an average and a homogeneous size of 20-25 nm and a spherical morphology with a fuel to raw material ratio of 1 , concentration value of 0.2 and $\mathrm{pH}$ value of 0.5 . The most appropriate ratio for the fuel to raw material was found to be 1 .

\section{References}

[1] Hara K, Arakawa H, Luque A and Hegedus S 2003 A Luque handbook of photovoltaic science and engineering (NY: John Wiley \& Sons Ltd) p 663

[2] Fortunato E, Ginley D, Hosono H and Paine D C 2007 MRS Bull. 32242

[3] Li B, Huang L, Zhou M and Wu B 2014 Ceram. Int. 401627

[4] Kawashima T, Ezure T, Okada K, Matsui H, Goto K and Tanab N 2004 J. Photochem. Photobiol. 164199

[5] Tatar D, Turgut G and Duzgun B 2013 Rom. J. Phys. 58 143

[6] Bhardwaj A, Gupta B K, Raza A, Sharma A K and Agnihotri O P 1981 Sol. Energy Mat. Sol. C 539

[7] Naje A N, Norry A S and Suhail A M 2013 Int. J. Innov. Res. Sci. Eng. Technol. 427068

[8] Farrukh M A, Heng B and Adnan R 2010 Turk. J. Chem. 34 537

[9] Han C H, Jousseaume B, Rascle M C, Toupance T, Cacher H and Vivier V 2004 J. Fluor. Chem. 1251247
[10] Razeghizadeh A R, Rafee V and Zalaghi L 2015 Mesoscale and nanoscale physics (cond-mat.mes-hall) 142 arXiv:1502.00219

[11] Senthilkumar V, Vickraman P and Ravikumar R 2010 J. Sol. Gel. Sci. Technol. $\mathbf{5 3} 316$

[12] Adnan R, Razana N, Rahman I A and Farrukh M A 2010 J. Chin. Chem. Soc. 57222

[13] Han C H, Han S D, Gwak J and Khatkar S P 2007 Mater. Lett. 611701

[14] Yue Z, Li L, Zhou J, Zhang H and Gui Z 1999 Mater. Sci. Eng. B 6468

[15] Ahmed W and Jackson M J 2009 Emerging nanotechnologies for manufacturing (UK: Elseiver Science and Technology Books)

[16] Telford J K 2007 A brief introduction to design of experiments (Washington: Johns Hopkins APL Technical Digest) p 224

[17] Antony J 2003 Design of experiments for engineers and scientists (Amsterdam: Elsevier Science \& Technology Books)

[18] Leiviskä K 2013 Introduction to experiment design (University of Oulu) p 31

[19] Kehoe S, Ardhaoui M and Stokes J 2011 J. Mater. Eng. Perform. 201423

[20] Askari-Paykani M, Shayan M and Shamanian M 2014 J. Iron Steel Res. Int. 21252

[21] Software Help Design-Expert Software, Version 7.12007 User's guide, technical manual (Minneapolis, MN: Stat-Ease Inc.)

[22] Nekouei R K, Rashchi F and Amadeh A 2013 Powder Technol. 237165

[23] Sikhwivhilu L M, Pillai S K and Hillie T K 2011 J. Nanosci. Nanotechnol. 114988

[24] Li Z, Shen W, Zhang X, Fang L and Zu X 2008 Colloids Surf. A: Physicochem. Eng. Asp. 17327

[25] Bruneaux J, Cachet H, Froment M, Levart M, and Vedel J 1989 J. Microsc. Spectrosc. Electron. 141

[26] Riahi-Noori N, Sarraf-Mamoory R, Alizadeh P and Mehdikhani A 2008 J. Ceram. Process. Res. 9246 